\title{
Vitamin D and Autoimmune Thyroid Disease-Cause, Consequence, or a Vicious Cycle?
}

\author{
Inês Henriques Vieira ${ }^{1, *}$, Dírcea Rodrigues ${ }^{1,2}$ and Isabel Paiva ${ }^{1}$ \\ 1 Endocrinology Department of Coimbra Hospital and University Centre, Praceta Professor Mota Pinto, \\ 3004-561 Coimbra, Portugal; dircearodrigues@chuc.min-saude.pt (D.R.); isapaiva@chuc.min-saude.pt (I.P.) \\ 2 Faculty of Medicine of the University of Coimbra, R. Larga 2, 3000-370 Coimbra, Portugal \\ * Correspondence: 11285@chuc.min-saude.pt
}

Received: 17 July 2020; Accepted: 9 September 2020; Published: 11 September 2020

\begin{abstract}
Vitamin D is a steroid hormone traditionally connected to phosphocalcium metabolism. The discovery of pleiotropic expression of its receptor and of the enzymes involved in its metabolism has led to the exploration of the other roles of this vitamin. The influence of vitamin D on autoimmune disease - namely, on autoimmune thyroid disease- - has been widely studied. Most of the existing data support a relationship between vitamin D deficiency and a greater tendency for development and/or higher titers of antibodies linked to Hashimoto's thyroiditis, Graves' disease, and/or postpartum thyroiditis. However, there have also been some reports contradicting such relationships, thus making it difficult to establish a unanimous conclusion. Even if the existence of an association between vitamin $\mathrm{D}$ and autoimmune thyroid disease is assumed, it is still unclear whether it reflects a pathological mechanism, a causal relationship, or a consequence of the autoimmune process. The relationship between vitamin D's polymorphisms and this group of diseases has also been the subject of study, often with divergent results. This text presents a review of the recent literature on the relationship between vitamin $\mathrm{D}$ and autoimmune thyroid disease, providing an analysis of the likely involved mechanisms. Our thesis is that, due to its immunoregulatory role, vitamin D plays a minor role in conjunction with myriad other factors. In some cases, a vicious cycle is generated, thus contributing to the deficiency and aggravating the autoimmune process.
\end{abstract}

Keywords: Vitamin D; autoimmune thyroid disease; Vitamin D receptor; Graves' disease; Hashimoto thyroiditis

\section{Introduction}

The term vitamin D (VitD) encompasses a group of steroid compounds, namely VitD2 (ergocalciferol) and VitD3 (cholecalciferol) [1].

Its main functions are the regulation of phosphocalcium metabolism and the promotion of bone homeostasis. However, the discovery of the widespread expression of the VitD receptor (VDR) and the enzymes responsible for its metabolism suggests the pleiotropic role of this vitamin and its influence in several diseases [2,3]. An immunomodulatory role is evident and its influence on the development of autoimmune diseases (AID) has been proposed. Autoimmune thyroid disease (AITD) is the most common organ-specific AID [3] and several studies have been carried out to explore the role of VitD in its development and course, as well as the possible impact of supplementation.

The aim of this review is to analyze the most recent evidence on the relationship between VitD and AITD. 


\section{Materials and Methods}

A search was conducted in Pubmed using the Medical Subject Headings (MESH) terms "vitamin D" and "thyroid disease" for publications from January 2009 to July 2020. Articles with full text in English, Portuguese, or Spanish $(n=205)$ were selected based on their title and/or abstract. Articles focusing on nodular thyroid disease (benign or malignant), parathyroid disease, or otherwise not referring to autoimmune thyroid disease were excluded at this stage. Additional articles were excluded after reading the full text if they did not relate to the study matter or if the information provided was redundant. The bibliographies of the publications thus selected were also analyzed, with the inclusion of additional relevant articles published in the same time interval. Further research was conducted to provide context and to answer particular questions which emerged upon reading the selected articles or during the peer-review process (Figure 1).

\section{Pubmed search for articles containing the Medical Subject Headings (MESH) terms "Vitamin D" AND "Thyroid Diseases" published from January 2019 to july 2020, written in English, Portuguese and Spanish 205 articles found}

\section{2 articles excluded based on title and/or abstract \\ $\downarrow \quad 8$ articles excluded after full text reading}

\section{5 articles initially included in the review}

$\downarrow \begin{aligned} & 33 \text { added upon review of the bibliography of consulted } \\ & \text { publications } \\ & 21 \text { added to provide context and/or address specific } \\ & \text { questions that emerged during research or the peer- } \\ & \text { review process }\end{aligned}$

\section{9 articles included in the review}

Figure 1. Literature search process.

\section{Metabolism and Functions of Vitamin D}

In humans, VitD3 is produced in the skin under the action of ultraviolet light on 7-desidroxicolesterol $[1,4,5]$. Additionally, it can be obtained nutritionally, predominantly from fish oil and eggs [4,5]. In fungi and plants, VitD2 is synthesized from ergosterol [5].

There are three essential steps in the metabolism of this vitamin, which are carried out by cytochrome P450 oxidases: 25 -hydroxylation, which produces $25(\mathrm{OH}) \mathrm{D}$ (calcidiol); $1 \alpha$ - hydroxylation, which generates $1,25(\mathrm{OH})_{2} \mathrm{D}$ (calcitriol); and 24-hydroxylation, which inactivates $25(\mathrm{OH}) \mathrm{D}$ and $1,25(\mathrm{OH})_{2} \mathrm{D}$ (preferentially), preventing the accumulation of toxic levels [4-6]; see Figure 2.

25(OH)D has little biological activity [2], but is the main circulating form, being considered to best reflect an organism's reserves. As such, its quantification is widely used to assess the levels of VitD [7]. Conversion to $1,25(\mathrm{OH})_{2} \mathrm{D}$ requires the action of $1 \alpha$-hydroxylase (CYP27B1). Although the majority of human cells express this enzyme, levels of $1,25(\mathrm{OH})_{2} \mathrm{D}$ seem to reflect its activity in the cells of the 
proximal tubules of the kidney [7]. In these cells, its activity is stimulated by parathyroid hormone (PTH) and is inhibited by fibroblast growth factor-23 (FGF23) and by $1,25(\mathrm{OH})_{2} \mathrm{D}$ itself [5].

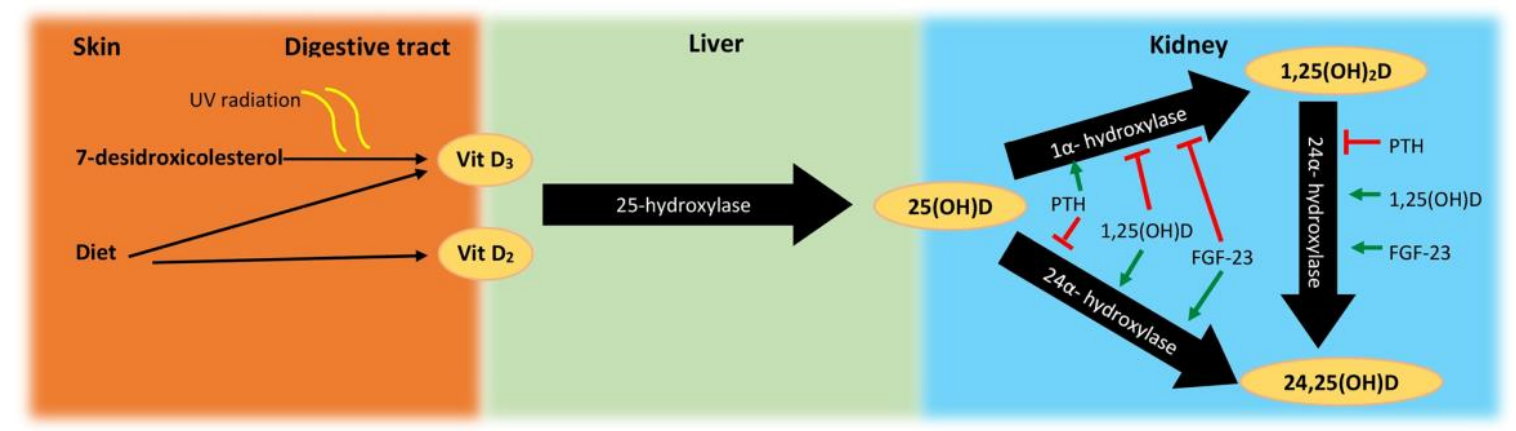

Figure 2. Schematic representation of vitamin $\mathrm{D}$ metabolism. UV, ultraviolet; Vit $\mathrm{D}_{2}$, vitamin $\mathrm{D}_{2}$; $\mathrm{VitD}_{3}$, vitamin $\mathrm{D}_{3} ; \mathrm{PTH}$, parathyroid hormone; FGF-23, fibroblast growth factor 23.

CYP24A1 is the only established 24-hydroxylase, which has an inverse regulation from the kidney's $1 \alpha$-hydroxylase, as it is induced by $1,25(\mathrm{OH})_{2} \mathrm{D}$ and FGF23 [5].

Most other human cells include $1 \alpha$-hydroxylase and VDR, but seem to essentially regulate the levels of $1,25(\mathrm{OH})_{2} \mathrm{D}$ on a tissue level [7], which may be subject to different regulatory mechanisms than those in renal cells [5].

The main function of $1,25(\mathrm{OH})_{2} \mathrm{D}$ is to increase calcium absorption from the intestines and, along with PTH, it contributes to maintaining serum calcium levels. When there is a low VitD status, PTH levels tend to rise, in order to compensate for impaired intestinal calcium absorption [8].

VitD exerts most of its effects by binding to the nuclear receptor VDR, which dimerizes with the retinoid $X$ receptor; this heterodimer binds to VitD-responsive genes [9]. Rapid actions, independent of gene transcription [10], which modulate intracellular calcium levels and several signaling pathways have also been described. Thus, this compound can directly or indirectly influence up to $5 \%$ of the human genome. A randomized controlled clinical trial evaluated gene expression in the white blood cells of eight adults after daily supplementation with 400 and 2000 UI of VitD3. There was a differential expression of $\geq 291$ genes involved in functions such as cell proliferation and differentiation, immune function, and DNA repair in a continuous manner with increasing levels of 25(OH)D [11].

Therefore, it is not surprising that, in addition to having been implicated in several skeletal diseases, the hypothesis has been raised regarding the association of VitD with neoplasms, cardiovascular disease, metabolic diseases, infections, AID, and neurocognitive dysfunction [12]. However, a clear role has not been definitively established for any of these conditions [13].

\section{Vitamin D and Immune Modulation}

The immune system defends the organism against what is recognized as non-self. Failure to recognize the body's cells as the self generates autoimmune phenomena, which may be physiological (elimination of unnecessary cells) or pathological (AID) [14].

Given the immunomodulatory role of VitD, its relationship with AID has been extensively explored. Evidence of associations between VitD deficiency and several AIDs has been presented; namely, multiple sclerosis, systemic sclerosis, systemic lupus erythematosus, Sjögren's syndrome, mixed connective tissue disease, rheumatoid arthritis, antiphospholipid syndrome, type 1 diabetes mellitus, AITD, celiac disease, and primary biliary cirrhosis [14]. In a population-based longitudinal study, Skaaby et al. observed a decreased risk of AID in general, and thyrotoxicosis in particular, with each increment of $4 \mathrm{ng} / \mathrm{mL}(10 \mathrm{nmol} / \mathrm{L})$ on the level of $25(\mathrm{OH}) \mathrm{D}$ (hazard ratios of 0.94 and 0.83 , respectively) [15]. Additionally, birth month can influence the risk of developing AID, most likely in relation to exposure to ultraviolet radiation [14]. 
In general, VitD tends to activate the innate immune response and to regulate the adaptative immune response $[5,6,14]$. VitD appears to have the ability to stimulate the differentiation of monocytes into macrophages and the production of antibacterial substances by these cells, promoting an initial response [9,16], but also helps to avoid excessive innate responses and consequent tissue damage [16].

Concerning the regulation of adaptative immunity, the result of antigen presentation to $\mathrm{T}$ cells differs when performed by immature or mature dendritic cells (Figure 3), promoting tolerance or an immune response, respectively [9]. Physiological levels of $1,25(\mathrm{OH})_{2} \mathrm{D}$ inhibit the maturation of dendritic cells and maintain a more tolerogenic phenotype [17]. As dendritic cells become more mature, they express more $1 \alpha$-hydroxylase and less VDR. As a consequence, mature antigen-presenting dendritic cells can be relatively insensitive to the action of $1,25(\mathrm{OH})_{2} \mathrm{D}$, allowing for the induction of an initial $\mathrm{T}$ response. However, they synthesize $1,25(\mathrm{OH})_{2} \mathrm{D}$, which acts on a paracrine level on immature dendritic cells and prevents their excessive proliferation [16]. Dendritic cells generated with the use of biologically active forms of VitD have high immunoregulatory capacity [18] while maintaining cell mobility [19].

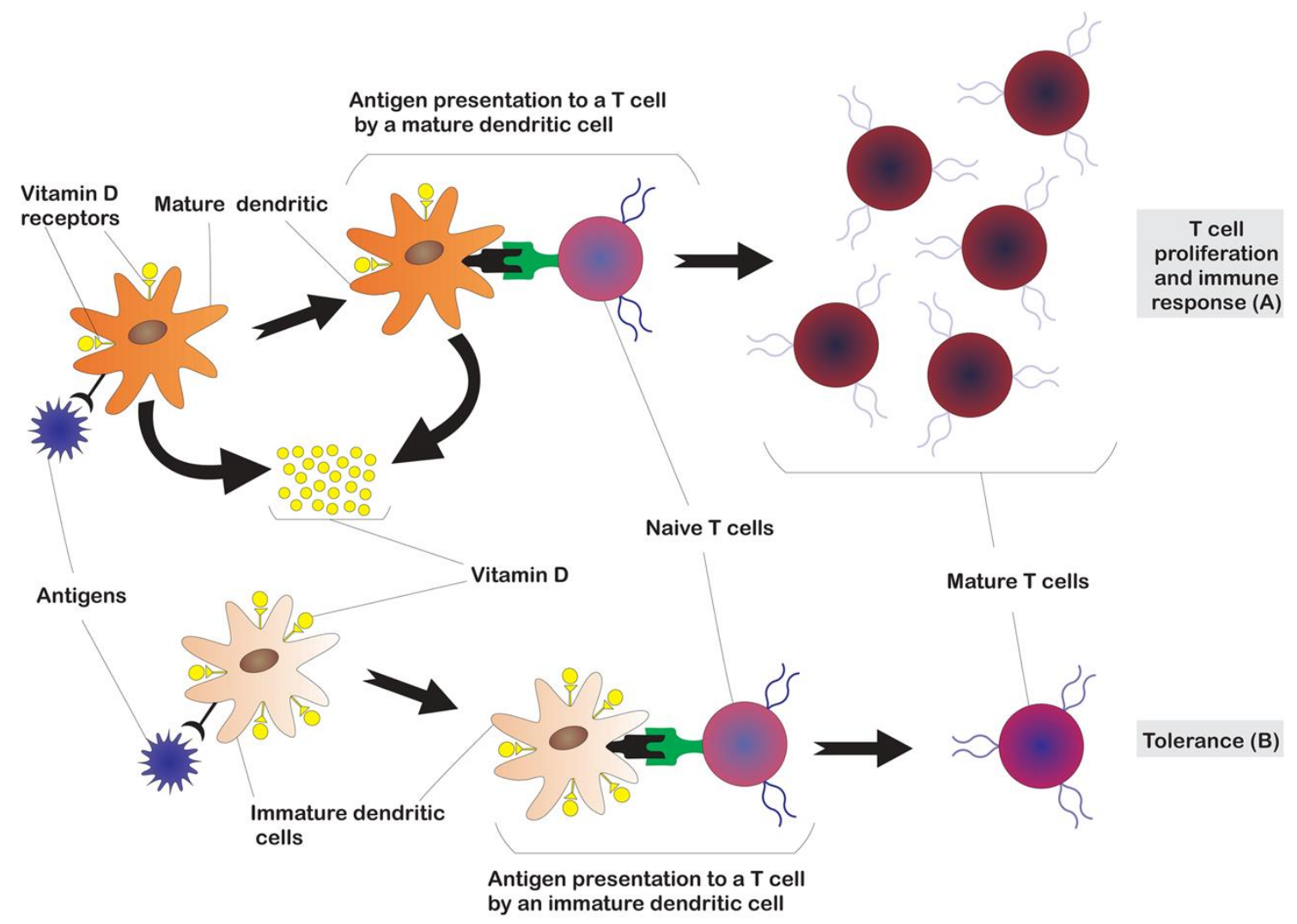

Figure 3. Influence of vitamin D in activation of adaptative immunity. The different results of antigen presentation to $\mathrm{T}$ cells by mature vs. immature dendritic cells, leading to immune response (A) or tolerance (B), respectively, are depicted. Vitamin D inhibits the maturation of dendritic cells, maintaining a more tolerogenic phenotype. Mature dendritic cells have less vitamin D receptor (VDR) but synthesize $1,25(\mathrm{OH})_{2} \mathrm{D}$, which acts on a paracrine level on immature dendritic cells and prevents their excessive proliferation.

VitD also plays a role in the regulation of adaptive immunity. B and $\mathrm{T}$ lymphocytes have low VDR expression at rest and higher expression when activated. An ability to synthetize VitD was also detected, which plays a regulatory role, acting in an autocrine/paracrine fashion [16].

Previous studies have led to the conclusion that VitD has a role in promoting the change from Th1 to Th2 phenotype, limiting the damage induced by the cellular immune response [17]. However, it has been found that, in vivo, the effects of VitD on T cells are more complex $[16,17]$. 
In T cells, $1,25(\mathrm{OH})_{2} \mathrm{D}$ inhibits the proliferation of Th17 (linked to organ-specific autoimmunity, inflammation, and tissue damage), appears to induce regulatory $\mathrm{T}$ cells (Treg), which have a suppressive role in the proliferation of $\mathrm{T}$ cells, and helps direct $\mathrm{T}$ cells to tissues. FoxP3 is important in Treg cell development, and VitD levels have been found to be associated with FoxP3 expression in 32 children with chronic autoimmune thyroiditis. An increase in FoxP3 expression has been observed after VitD supplementation [20]. Additionally, VitD can reduce the production of cytokines by CD8+ T cells and regulate their proliferation after specific stimuli, although a significant effect has not been shown in animal models [16].

In B cells, $1,25(\mathrm{OH})_{2} \mathrm{D}$ has a direct and indirect regulatory role (through $\mathrm{T}$ helper cells), seeming to inhibit their differentiation and the production of immunoglobulins [16].

\section{Vitamin D and Autoimmune Thyroid Disease}

AITD is the most common AID, with a prevalence of around 5\% [21,22].

Autoimmunity requires an autoantigen to which the individual is normally tolerant and a process which leads to breaking that tolerance [23]. The potential autoantigens in the thyroid are the thyroid stimulating hormone (TSH) receptor (TSH-R), thyroid peroxidase (TPO), and thyroglobulin (Tg). Autoimmunity to these antigens leads to the creation of anti-thyroid antibodies. Anti-TPO and anti-Tg are usually associated with chronic autoimmune thyroiditis/Hashimoto thyroiditis (HT), and TSH-R (TRABs) with Graves' disease (GD) [24].

Both GD and HT are characterized by lymphocytic infiltration of the thyroid parenchyma. In GD, the infiltration is mild, such that the gland remains intact but TRABs play a central role in stimulating the gland's function and growth. In HT, the lymphocytic infiltrate causes the destruction of the follicles, which may lead to hypothyroidism [21]. In the thyroid tissue, the recruitment of Th1 lymphocytes may increase the production of interferon-y and tumor necrosis factor- $\alpha$, which stimulate the secretion of CXCL10 by thyroid cells and create a positive feedback, thus initiating and perpetuating the autoimmune process [22].

$\mathrm{B}$ cells are found in secondary lymphoid follicles in the thyroid tissue and produce antibodies spontaneously, making the thyroid the probable main source of autoantibodies in AITD [21].

AITD has a multifactorial etiology, influenced by genetic factors (e.g., polymorphisms of TSH-R, Tg, human leukocyte antigens, and other genes associated with the immune response) [24], environmental factors (e.g., radiation, iodine, smoking habits, infections, selenium, drugs, stress, and dietary habits) $[21,24,25]$, and endogenous factors (e.g., body mass index, adipokines, estrogens, selective $X$ chromosome inactivation, microquimerism, glucocorticoids [21], and potentially the gastrointestinal microbiome) [26-28]. Given the immunomodulatory role of VitD, its relationship with AITD has been extensively studied in recent years [29].

\subsection{Data on Vitamin D and Thyroid Function}

A role in the modulation of the hypothalamic-pituitary-thyroid axis has been proposed for VitD, both at the pituitary [30] and thyroid gland levels [31]. Previous studies have reported the presence of VDR in murine thyrotropic cells [31]. A strong molecular homology between VDR and thyroid hormone has been demonstrated, as well as the presence of VDR in murine follicular thyroid cells. The incubation of these cells with $1,25(\mathrm{OH})_{2} \mathrm{D}$ inhibited the uptake of iodine and cell growth [32].

Barchetta et al. studied the seasonality of TSH levels in euthyroid adults and found a strong inverse correlation between this hormone and $25(\mathrm{OH}) \mathrm{D}$, with TSH levels being highest in autumn-winter and 25(OH)D levels being highest in spring-summer [31]. The relationship between the season of birth and risk of AITDs has also been evaluated, with inconsistent results. No impact of birth month in GD and discretely higher birth rates in autumn in HT females were reported in a study with data from Europe (mostly from the U.K.) [33]. A higher risk of autoimmune thyroiditis in subjects born in summer [34] and no relationship between month of birth and GD [35] were described in Danish register-based studies. A higher frequency of birth in spring was noticed in Greek children with 
HT [36]. Seasonality of birth month may be related to VitD levels (higher frequency of deficit in the end of winter, beginning of spring), but also may relate to viral exposure and other factors which vary in different regions and years [36].

Mackawy et al. also found an inverse relationship between VitD levels and TSH values, with a high prevalence of hypovitaminosis D and hypocalcemia in patients with hypothyroidism [37]. Two population-based studies corroborated these data in young people [38], as well as in middle-aged and elderly men with negative anti-thyroid antibodies [39]. A study performed in Korea revealed that iodine excess was associated with thyroid dysfunction only in VitD-deficient individuals [40].

In patients with AITD, Vondra et al. found a positive relationship between $25(\mathrm{OH}) \mathrm{D}$ levels and the fT4/fT3 ratio, which disappeared after supplementation with cholecalciferol. The authors speculated that the decreased ratio may be a compensatory adaptation to VitD deficiency [41].

\subsection{Data on Vitamin D Levels and Autoimmune Thyroid Disease}

Most data on VitD and AITD have come from cross-sectional studies and tend to support the existence of an association.

Kivity et al. reported an association between VitD deficiency, defined as $25(\mathrm{OH}) \mathrm{D}<10 \mathrm{ng} / \mathrm{mL}$ ( $25 \mathrm{nmol} / \mathrm{L}$ ), and a higher frequency of AITD (mainly HT) and the presence of thyroid antibodies, in general [42]. Unal et al. found lower levels of 25(OH)D in individuals with AITD, with the GD group registering lower levels than those with HT and an inverse correlation between the levels of 25(OH)D and antithyroid antibody titers [43]. Another cross-sectional study examined 25(OH)D levels in 140 people with AITD versus 70 controls and found lower levels in the study group. Higher levels of $25(\mathrm{OH}) \mathrm{D}$ had a weak correlation with lower TRABs, but were not associated with anti-TPO/Tg titers [44]. In a meta-analysis in 2015, Wang et al. reported lower levels of 25(OH)D and higher prevalence of deficiency in individuals with AITD vs. controls. In sub-group analysis, the relationship remained when HT and GD patients were analyzed separately [45].

A role of VitD has also been proposed in polycystic ovary syndrome (PCOS); these patients had a high prevalence of AITD, making it plausible that there was a pathophysiological association. Muscogiuri et al. evaluated 50 women with PCOS and found lower 25(OH)D levels in those who also had AITD [46].

However, there are also data that contradict the presence of an association between VitD and AITD. D'Aurizio et al. did not find a statistically significant difference in the levels of VitD in AITD patients when compared to healthy controls [47]. Effraimidis et al. compared euthyroid individuals without anti-thyroid antibodies and with a family history of AITD (used as a marker for genetic pre-disposition) versus individuals without anti-thyroid antibodies and with no family history of AITD. The authors found higher levels of $25(\mathrm{OH}) \mathrm{D}$ in those with a family history. In a longitudinal analysis by the same authors, individuals who developed de novo anti-TPO antibodies were compared with control subjects, with no statistically significant difference in the levels of $25(\mathrm{OH}) \mathrm{D}$ or $1,25(\mathrm{OH})_{2} \mathrm{D}$ at baseline, nor at the time of seroconversion [48].

A study comparing pre-/post-menopausal women and men with AITD found an association of AITD and VitD levels only in pre-menopausal women. These data raise the possibility of an interaction between VitD and estrogens in the development of AITD. 17- $\beta$ estradiol may play a protective role by suppressing the transcription of CYP24A1, increasing VDR biosynthesis, inducing greater binding, and internalizing D-binding protein to T cells and macrophages [49]. The results from an analysis of the 6th Korean National Health and Nutrition Study Examination Survey corroborate this hypothesis, with lower VitD levels in anti-TPO-positive women (but not men) and an association of lower VitD with thyroid dysfunction exclusively in TPO-positive pre-menopausal woman [50].

\subsubsection{Data in Hashimoto's Thyroiditis/Chronic Autoimmune Thyroiditis}

There is evidence supporting a relationship between vitamin D and HT. Tamer et al. identified lower 25(OH)D levels in individuals with HT versus control subjects, with a tendency for a higher prevalence 
of deficiency in patients with hypothyroidism than in those in euthyroidism [51]. Studies in other populations corroborated the association between lower levels of $25(\mathrm{OH}) \mathrm{D}$ and the risk of HT, namely Bozkurt et al. 2013 [52]; Mansournia et al. 2014 [53]; Vondra et al. 2015 [7]; Maciejewski et al. 2015 [54]; Kim D et al. 2016 [55]; Giovinazzo et al. 2017 [56]; Ke et al. 2017 [57]; and Pergola et al. 2018 [58].

There are also data supporting this relationship at age extremes. A higher prevalence of AITD and anti-TPO titers in association with $25(\mathrm{OH}) \mathrm{D}<20 \mathrm{ng} / \mathrm{mL}(\sim 50 \mathrm{nmol} / \mathrm{L})$ was found in individuals over 65 years of age. It should be noted, however, that the AITD group was older and had higher creatinine levels [59]. In pediatric patients with HT vs. healthy controls, a higher prevalence of VitD deficiency was also found [60-63]. However, in an analysis of pediatric patients with type $1 \mathrm{DM}$ with vs. without HT, 25(OH)D levels $<20 \mathrm{ng} / \mathrm{mL}$ were found in both groups, with no difference between the two [64].

The relationship with antibody titers is characterized by more inconsistent data. Bozkurt et al. reported a correlation between $25(\mathrm{OH}) \mathrm{D}$ deficiency severity, duration of $\mathrm{HT}$, thyroid volume, and antibody titers [52]. An inverse correlation between 25(OH)D and anti-TPO was also verified by Giovinazzo et al. in recently diagnosed euthyroid HT patients vs. control subjects [56]; by Arslan et al. in healthy subjects with moderate-severe 25(OH)D deficiency [65]; and by Shin et al. in individuals with AITD [66]. Goswami et al. detected only a weak correlation between the levels of 25(OH)D and anti-TPO [67]. Wang et al. found a negative correlation between the levels of $25(\mathrm{OH}) \mathrm{D}$ and anti-Tg, but not anti-TPO [68]. Ke et al. found no relationship with thyroid function, antibody titers, and serum cytokines in a group with HT [57]. Sönmenzgöz et al. found no correlation between the levels of $25(\mathrm{OH}) \mathrm{D}$ and anti-TPO in a pediatric population [60]. An absence of correlation between the levels of $25(\mathrm{OH}) \mathrm{D}$, anti-TPO, and anti-Tg was also observed in two population-based studies in Thailand [38] and China [39].

The results obtained by Yasmeh et al. contradict most of the published data, indicating higher levels of $25(\mathrm{OH}) \mathrm{D}$ in women with HT vs. controls (no difference in males) and a positive correlation between levels of 25(OH)D and anti-TPO titers only in males [69].

VitD may also affect disease manifestations: $\mathrm{Xu}$ et al. reported a highly significant correlation between mild cognitive impairment (defined as a Montreal Cognitive Assessment score $<26$ ) and 25(OH)D deficiency in adult patients with HT, in both univariate and multivariate analyses [70].

The effect of this steroid hormone may depend on its interaction with other factors. For instance, there exist data suggesting that adequate levels of 25(OH)D allow an anti-inflammatory and immunomodulatory effect of simvastatin, with a consequent reduction in the levels of anti-TPO and anti- $\operatorname{Tg}[71,72]$.

\subsubsection{Data in Graves' Disease}

Data on the relationship between VitD and GD are more scarce. Misharin et al. investigated the response to TRABs induction by immunizing two BALB/c and C57BL/6 murine strains receiving VitD-sufficient or -depleted diet. BALB/c strains are more susceptible to disease induction and displayed a reduced ability to convert $25(\mathrm{OH}) \mathrm{D}$ to $1,25(\mathrm{OH})_{2} \mathrm{D}$ when compared C57BL/6 strains. The authors found that $\mathrm{BALB} / \mathrm{c}$ mice had a slightly different immune response, depending on the diet administered; however, the main difference was the greater probability of developing persistent hyperthyroidism [73].

Several studies have reported lower levels of serum 25(OH)D in GD patients [74-77]; however, there were important differences in the results. The study by Zhang et al. reported an association between VitD levels and TRAB titers [75], while the remaining studies did not support such an association [74,76,77]. Yasuda et al. described an association with greater thyroid volume [74]; conversely, Mangaraj et al. found no differences in glandular volume between VitD-deficient and non-deficient GD patients [77]. Two metanalyses from 2015 reported a greater probability of 25(OH)D deficiency in individuals with GD [45,78].

Levels of 25(OH)D may be important in the response to treatment, with lower levels being associated with a lower likelihood of remission [79] and higher recurrence rate [80] when anti-thyroid drug therapy is used. Contrary to these findings, Planck et al. found no association between VitD levels at 
baseline and relapse within 1 year of completion of a 18 month anti-thyroid drug cycle [76]. Serum levels of $25(\mathrm{OH}) \mathrm{D}<20 \mathrm{ng} / \mathrm{mL}$ were also identified as an independent risk factor for therapeutic failure with radioactive iodine [81]. Furthermore, cases of symptomatic hypocalcemia have been reported following GD treatment; not only surgical, but also after radioiodine [82] and with methimazole [83]. In both cases, low 25(OH)D levels and high compensatory $1,25(\mathrm{OH})_{2} \mathrm{D}$ levels were reported, and prior VitD deficiency was appointed as a possible contributing cause [82,83]. However, in the case following radioiodine therapy, PTH was inappropriately normal and prior hypoparathyroidism, although unlikely, could not be excluded [82].

\subsubsection{Data on Postpartum Thyroiditis (PPT)}

Analyses performed on women with PPT also identified a relationship between lower levels of $25(\mathrm{OH}) \mathrm{D}$ and development of the disease $[44,84]$. Regarding anti-thyroid antibody titers, the results differ: while Krysiak et al. reported a negative correlation with the levels of 25(OH)D [84], Ma et al. found no relationship [44].

The inability to reach clear conclusions is partly due to limitations in the design of the studies, which were mostly cross-sectional with limited samples, heterogeneous populations, different latitudes and seasonality of blood sampling, variable criteria for defining AITD, and different cutoffs for defining insufficiency and deficiency of $25(\mathrm{OH}) \mathrm{D}$. It is also necessary to take into account the possible interaction with several factors influencing the association (e.g., age, body mass index, ethnicity, other hormone levels, and so on).

\subsection{Polymorphisms of Genes Associated with Vitamin D and AITD}

An association has been hypothesized between polymorphisms of genes involved in the function and metabolism of VitD and AITD.

The most widely studied polymorphisms in this context are those of the VDR gene. This gene is located on chromosome 12q13.11 and contains 14 exons and about 75 kilobases. Several single nucleotide polymorphisms (SNP) have been identified in this gene, some of which have been associated with a risk of AITD [85]. The four main SNPs which have been described are Fok1 (rs10735870), BsmI (rs1544410), ApaI (rs7975232), and TaqI (rs731236); the latter three are in linkage disequilibrium with each other [56].

The results of association studies of VDR polymorphisms with AITD are inconsistent, even when meta-analyses were used to obtain a higher statistical power [85-88]. Table 1 summarizes the main data of the four meta-analyses on this subject published within the time frame reviewed in this text.

Table 1. Meta-analyses summarizing the association between VDR polymorphisms and AITD.

\begin{tabular}{|c|c|c|c|c|}
\hline Autor & N Included Studies & PMF & $\begin{array}{c}\text { Population } \\
\text { (Cases/Controls) }\end{array}$ & Main Results \\
\hline \multirow{4}{*}{$\begin{array}{l}\text { Zhou H., Xu C., and Gu } \\
\text { C., 2009 (data from } \\
\text { 2000-2008) [86] }\end{array}$} & \multirow{4}{*}{$\begin{array}{c}\text { Nine on the relationship } \\
\text { between VDR-PMF } \\
\text { relationship with } \\
\text { GD }\end{array}$} & ApaI & $1820 / 1866$ & $\begin{array}{l}\text { Increased risk of GD in Asians (OR 1.31) } \\
\text { No statistical association in Caucasians }\end{array}$ \\
\hline & & BsmI & $1815 / 2066$ & $\begin{array}{l}\text { Increased risk of GD in Asians (OR 1.58) } \\
\text { No statistical association in Caucasians }\end{array}$ \\
\hline & & TaqI & $1348 / 1175$ & No statistical association in Caucasians \\
\hline & & FoxI & $1662 / 1840$ & $\begin{array}{l}\text { Increased risk of GD in Asians (OR 1.68) } \\
\text { No statistical association in Caucasians }\end{array}$ \\
\hline \multirow{4}{*}{$\begin{array}{l}\text { Feng M. et al. } 2012 \text { (data } \\
\text { up to 08/2012) [87] }\end{array}$} & \multirow{4}{*}{$\begin{array}{c}\text { Eight on the relationship } \\
\text { between VDR-PMF with } \\
\text { AITD }\end{array}$} & ApaI & $1009 / 1080$ & No statistical association \\
\hline & & BsmI & $1158 / 1049$ & Risk decreased B allele vs. b (OR 0.801) \\
\hline & & TaqI & $1211 / 1184$ & Risk decreased t allele vs. T (OR 0.854) \\
\hline & & FoxI & $739 / 924$ & No statistical association \\
\hline
\end{tabular}


Table 1. Cont.

\begin{tabular}{|c|c|c|c|c|}
\hline Autor & N Included Studies & PMF & $\begin{array}{c}\text { Population } \\
\text { (Cases/Controls) }\end{array}$ & Main Results \\
\hline \multirow{4}{*}{$\begin{array}{l}\text { Gao X. and Yu Y., } 2017 \\
\text { (data until 08/2017) [85] }\end{array}$} & \multirow{4}{*}{$\begin{array}{c}\text { Two on the relationship } \\
\text { between VDR-PMF with } \\
\text { AITD }\end{array}$} & ApaI & $3544 / 3117^{1}$ & $\begin{array}{c}\text { Increased risk in Africans (OR 3.62) } \\
\text { No statistical association in general }\end{array}$ \\
\hline & & BsmI & $3636 / 3373^{1}$ & $\begin{array}{c}\text { Reduced risk in Europeans (OR 0.79) } \\
\text { and Africans (OR 0.42) } \\
{ }^{1} \\
\text { Increased risk in Asians (OR 1.41) }^{1}\end{array}$ \\
\hline & & TaqI & $2950 / 2254^{1}$ & $\begin{array}{l}\text { Reduced risk of HT in the African } \\
\text { population (OR } 0.33)^{1}\end{array}$ \\
\hline & & FoxI & $3174 / 2836^{1}$ & $\begin{array}{l}\text { Reduced risk of HT in the Asian } \\
\text { population (OR 0.65) }\end{array}$ \\
\hline \multirow{4}{*}{$\begin{array}{l}\text { Veneti S. et al. } 2019 \text { (data } \\
\text { up to } 12 / 2018 \text { ) [88] }\end{array}$} & \multirow{4}{*}{$\begin{array}{l}\text { Ten on the relationship } \\
\text { between VDR-PMF } \\
\text { relationship with } \\
\text { GD }\end{array}$} & ApaI & $2533 / 2474$ & No statistical association \\
\hline & & BsmI & $2536 / 2576$ & $\begin{array}{l}\text { No statistical association in general } \\
\text { Risk decreased in Asians (OR 0.67), but } \\
\text { increased in Caucasians (OR1.31) of } \\
\text { subtype bb }\end{array}$ \\
\hline & & TaqI & $2380 / 2235$ & Increased risk of GD with TT (OR 1.42) \\
\hline & & FoxI & $2587 / 2603$ & No statistical association \\
\hline
\end{tabular}

${ }^{1}$ Dominant model. Abbreviations: AITD, autoimmune thyroid disease; GD, Graves' disease; HT, Hashimoto thyroiditis; OR, odds ratio; PMF, polymorphism; VDR, vitamin D receptor.

Genome-wide association studies (GWAs) have shown that the genes encoding D-binding protein and CYP2R1 are associated with circulating VitD levels. Polymorphisms in these genes may be associated with treatment unresponsiveness in GD [89].

The somewhat divergent results of the polymorphism studies may be due, at least in part, to limited sample sizes, as the effect of each susceptibility locus is limited.

\section{Relevance of Supplementation}

The multitude of data suggesting a relationship between low levels of 25(OH)D and AITD have generated interest in the investigation of the use of VitD supplements in the prevention/treatment of this group of conditions.

Most recent results (Table 2) support the benefit of supplementation in individuals with AITD, which is generally higher in the presence of a deficiency, both in HT [90-94] and in TPP [84,95]. Three of the studies mentioned below also analyzed PTH and calcium levels at baseline and after supplementation, showing some degree of tendency towards the normalization of high PTH and low calcium levels [41,91,95].

Table 2. Prospective studies on AITD and VitD supplementation.

\begin{tabular}{|c|c|c|c|}
\hline Authors Study Type & Number of Subjects and Intervention & Results & Effect on $\mathrm{Ca}^{2+} / \mathrm{PTH}$ \\
\hline $\begin{array}{l}\text { Chaudhary S. et al. } \\
2016 \text { [91] Open-label RCT }\end{array}$ & $\begin{array}{l}\text { One hundred and two AITD subjects } \\
\text { randomized to receive cholecalciferol } \\
6000 \mathrm{IU}+\text { calcium } 500 \mathrm{mg} / \mathrm{d}(\mathrm{G} 1) \text { or } \\
\quad \text { only calcium }(\mathrm{G} 2) \\
\text { Positive response defined as a decrease } \\
\geq 25 \% \text { in anti-TPO titers. }\end{array}$ & $\begin{array}{l}\text { Response in } 68 \% \text { of G1 vs. } 44 \% \\
\text { of } \mathrm{G} 2 \\
\text { Only significant in those with TSH } \\
\leq 10 \mathrm{mUI} / \mathrm{mL} \text {. }\end{array}$ & $\begin{array}{l}\text { Higher PTH in those with lower } \\
25(\mathrm{OH}) \mathrm{D}_{2} \text {, no statistically } \\
\text { significant difference in } \mathrm{Ca}^{2+} \\
\text { and } \mathrm{P}^{-} \text {levels. } \\
\text { PTH reduction after } \\
\text { supplementation. }\end{array}$ \\
\hline $\begin{array}{l}\text { Krysiak R. et al. } 2016 \text { [95] } \\
\text { Longitudinal, } \\
\text { Case-Control trial }\end{array}$ & $\begin{array}{c}\text { Thirty-eight PPT vs. } 21 \text { healthy } \\
\text { postpartum women. } \\
\text { VitD supplementation in the subjects } \\
\text { with PPT: } \\
-4000 \mathrm{IU} / \text { day if deficiency } \\
{[25(\mathrm{OH}) \mathrm{D}<20 \mathrm{ng} / \mathrm{mL}]} \\
-2000 \mathrm{IU} / \text { day or no supplement for the } \\
\text { remaining patients }\end{array}$ & $\begin{array}{l}\text { Lower baseline } 25(\mathrm{OH}) \mathrm{D} \text { levels in } \\
\text { those with PPT. } \\
\text { After supplementation of VitD } \\
\text { according to baseline } \\
\text { values } \rightarrow \text { reduction in anti-TPO } \\
\text { titers, with a more marked effect in } \\
\text { those with deficiency at baseline. }\end{array}$ & $\begin{array}{c}\text { Higher PTH and lower } \mathrm{Ca}^{2+} \text { in } \\
\text { those with PPT. } \\
\text { Significant PTH reduction in } \\
\text { those with a deficiency of } \\
\text { 25(OH)D. }\end{array}$ \\
\hline $\begin{array}{l}\text { Simsek Y. et al. } 2016 \text { [96] } \\
\text { Longitudinal, RCT }\end{array}$ & $\begin{array}{c}\text { Eighty-two AITD patients } \\
-46 \text { were supplemented with VitD } 1000 \\
\text { IU/day for } 1 \text { month } \\
-36 \text { were not supplemented }\end{array}$ & $\begin{array}{l}\text { Reduction in anti-TPO and anti-Tg } \\
\text { titers only in the } \\
\text { supplementation group. }\end{array}$ & \\
\hline
\end{tabular}


Table 2. Cont.

\begin{tabular}{|c|c|c|c|}
\hline Authors Study Type & Number of Subjects and Intervention & Results & Effect on $\mathrm{Ca}^{2+} / \mathrm{PTH}$ \\
\hline $\begin{array}{l}\text { Krysiak R. et al. } 2017 \text { [92] } \\
\text { Longitudinal, } \\
\text { Case-Control trial }\end{array}$ & $\begin{array}{l}\text { Thirty-two women with HT, euthyroid, } \\
\text { or with sub-clinical hypothyroidism } \\
\text { and } 25(\mathrm{OH})>30 \mathrm{ng} / \mathrm{mL} \\
-18 \text { were supplemented with VitD } \\
2000 \text { UI/day for } 6 \text { months } \\
-16 \text { were not supplemented }\end{array}$ & $\begin{array}{l}\text { At baseline: inverse correlation of } \\
\text { 25(OH)D with antibody titers with } \\
\text { non-significant difference } \\
\text { between groups. } \\
\text { At } 6 \text { months: reduction in } \\
\text { antibody titers (mainly anti-TPO) } \\
\text { in relation to the increase in } \\
25(\mathrm{OH}) \mathrm{D} \text { only statistically } \\
\text { significant in those with } \\
\text { sub-clinical hypothyroidism (vs. } \\
\text { euthyroidism) and dependent on } \\
\text { baseline antibody titers. }\end{array}$ & \\
\hline $\begin{array}{l}\text { Krysiak R. et al. } 2019 \text { [93] } \\
\text { Non-randomized }\end{array}$ & $\begin{array}{l}\text { Thirty-two men with AITD in } \\
\text { euthyroidism } \\
\text {-20 supplemented with VitD } 4000 \mathrm{IU} / \text { day } \\
-17 \text { with selenomethionine } 200 \mu \mathrm{g} / \text { day }\end{array}$ & $\begin{array}{l}\text { Similar reduction in anti-TPO and } \\
\text { anti-Tg titers in both groups. } \\
\text { Greater effect of VitD on antibody } \\
\text { titers in those with } \\
25(\mathrm{OH}) \mathrm{D}<30 \mathrm{ng} / \mathrm{mL}(\sim 75 \mathrm{nmol} / \mathrm{L}) \\
\text { at baseline. }\end{array}$ & \\
\hline $\begin{array}{l}\text { Mazokopakis E. et al. } \\
2015 \text { [90] } \\
\text { Non-randomized }\end{array}$ & $\begin{array}{l}\text { From a group of } 218 \mathrm{HT} \text {, the } 186 \text { with } \\
25(\mathrm{OH})<30 \mathrm{ng} / \mathrm{mL} \text { were supplemented } \\
\text { with cholecalciferol } 1200-4000 \mathrm{IU} / \text { day. }\end{array}$ & $\begin{array}{l}\text { Negative correlation between } \\
\text { baseline } 25(\mathrm{OH}) \mathrm{D} \text { and anti-TPO. } \\
\text { Significant decrease in anti-TPO } \\
\text { after } 4 \text { months of } \\
\text { supplementation. }\end{array}$ & $\begin{array}{l}\text { No statistically significant } \\
\text { difference in } \mathrm{Ca}^{2+} \text { and } \mathrm{P}^{-} \text {at } \\
\text { baseline or after } \\
\text { supplementation. }\end{array}$ \\
\hline $\begin{array}{l}\text { Vondra K. et al. } 2017 \text { [41] } \\
\text { Non-randomized }\end{array}$ & $\begin{array}{l}\text { Thirty-seven women with AITD were } \\
\text { supplemented with } 4300 \mathrm{IU} / \text { day of } \\
\text { cholecalciferol for } 3 \text { months. }\end{array}$ & $\begin{array}{l}\text { Positive relationship between } \\
\text { fT4/fT3 ratio in patients with } \\
\text { AITD and } 25(\mathrm{OH}) \mathrm{D} \text { deficiency } \\
\text { which disappeared after } \\
\text { supplementation with } \\
\text { cholecalciferol. }\end{array}$ & $\begin{array}{l}\text { Correlation with higher PTH } \\
\text { and lower } \mathrm{Ca}^{2+} \text { at baseline. } \\
\text { Normalization after } \\
\text { supplementation. }\end{array}$ \\
\hline
\end{tabular}

In a systematic review and meta-analysis, Wang et al. concluded that supplementation with VitD appeared to significantly reduce levels of anti-TPO (for treatments $\geq 6$ months) and anti-Tg, with no reported serious adverse effects [97]. More recently, Koehler et al. retrospectively analyzed 933 patients with autoimmune thyroiditis and found a greater reduction in anti-TPO levels in a 58-patient sub-group that had an improvement in their initially insufficient VitD level $(<30 \mathrm{ng} / \mathrm{mL})$ vs. a control group that maintained a VitD level below the threshold. The difference between the groups, however, was not statistically significant [98].

Other factors may influence the effect of VitD supplementation on HT. Testosterone replacement in testosterone-deficient men has been associated with a more pronounced reduction in anti-TPO/-Tg titers and increased thyroid secretory capacity (SPINA-GT index) with VitD supplementation (vs. testosterone-naïve men) [99]. Selenomethionine supplementation has also been shown to enhance the effect of VitD on these parameters in 47 HT women [100].

Supplementation may also have a preventive component. A group of 11,017 participants in a wellness program were supplemented with VitD for over a year, aiming to reach physiological levels defined as $25(\mathrm{OH}) \mathrm{D}>40 \mathrm{ng} / \mathrm{mL}(100 \mathrm{nmol} / \mathrm{L})$. It was found that concentrations of $25(\mathrm{OH}) \mathrm{D} \geq 50 \mathrm{ng} / \mathrm{mL}$ $(125 \mathrm{nmol} / \mathrm{L}$ ) reduced the risk of hypothyroidism by $30 \%$ (from $0.4 \%-44$ cases $/ 11,017$ participants-to $0.28 \%-31$ cases) and elevated antibody titers by $32 \%$. Increased levels of $25(\mathrm{OH}) \mathrm{D}$ in patients with hypothyroidism have been associated with improved thyroid function [101].

Some recent studies evaluated the effects of VitD supplementation and outcomes in GD. Supplementation may delay the onset, but does not seem to prevent disease recurrence [102]. This intervention may have beneficial effects on cardiovascular outcomes (as suggested by a reduction in pulse wave velocity), which are limited to patients with VitD deficiency [103]. Conversely, VitD supplementation may be detrimental to muscle strength recovery [104].

It should be noted, however, that supplementation with excessive doses of $25(\mathrm{OH}) \mathrm{D}$ may be harmful. A possible increased risk of fractures has been reported with high-dose $25(\mathrm{OH}) \mathrm{D}$ supplementation [105]. In a large retrospective study, an association between 25(OH)D and mortality 
in the form of an inverted J-curve was suggested, with the lowest risk for serum levels between 20 and $24 \mathrm{ng} / \mathrm{mL}$ [106]. Therefore, it is important to emphasize that, indeed, some undesirable effects of attaining levels above the physiologic range may exist.

Given the paucity of data in this regard, a logical approach is to aim for VitD levels within the reference ranges suggested by international guidelines. The Institute of Medicine considers $20 \mathrm{ng} / \mathrm{mL}$ to be sufficient for most of the general population [107]. The Endocrine Society Guidelines, focused on individuals with risk of VitD deficiency, identify an optimal level of $25(\mathrm{OH}) \mathrm{D}>30 \mathrm{ng} / \mathrm{mL}$ and that values up to $100 \mathrm{ng} / \mathrm{mL}$ (250 nmol/L) are safe (as they do not cause hypercalcemia) [108].

\section{What Is the Nature of the Relationship between Vitamin D Levels and Autoimmune Thyroid Disease?}

Although there exists some inconsistency in the results of the studies carried out so far, most of the data are consistent with the presence of an association between vitamin D and AITD. However, there are several possible interpretations for this association.

The most commonly cited explanation is the decrease in the immunomodulatory role of $1,25(\mathrm{OH})_{2} \mathrm{D}$, in patients with deficiency, contributing to the development of AID. However, the data obtained to date are mostly resultant from cross-sectional studies, which do not allow for the establishment of causal effects. It is, therefore, essential to evaluate alternative explanatory models.

Some authors have raised the possibility that the various data favoring the involvement of VitD in AITD reflect a consequence, rather than a cause, of the disease. AID may lead to VitD deficiency by causing incapacitation and lower sunlight exposure, malabsorption, and the use of corticosteroids [42,109]. In hyperthyroidism, there may be accelerated bone turnover [32]. Kozai et al. found marked decreases in $1,25(\mathrm{OH})_{2} \mathrm{D}$ and CYP27B1 expression in rats with T3-induced hyperthyroidism [110]. In HT, the increase in fat mass caused by hypothyroidism could contribute to the deficiency [111]. Botello et al. studied 88 patients with long-term HT and found a positive correlation between 25(OH)D levels, fT4, and (contrary to expectations) Th17 and TNF $\alpha$. The authors hypothesized that low levels of fT4 are predictors of a deficiency of $25(\mathrm{OH}) \mathrm{D}$ and that the long evolution of the disease and treatment of hypothyroidism are related to a decrease in cytotoxic immune response, regardless of the levels of 25(OH)D [112]. The coexistence of AITD with other AID, such as celiac disease, also deserves consideration. Celiac disease leads to malabsorption with a deficiency of several nutrients [113], including VitD [114], and it is associated with an increased risk of developing other AIDs [113,114]. The presence of biopsy-proven celiac disease in patients with AITD is small, around 1.6\% according to a recent meta-analysis (although there may be some underdiagnosis) [115]; therefore, it cannot fully explain the reported lower values of VitD in all AITD patients. However, it is likely to contribute to this association in patients in which both diseases coexist. A group of HT patients with positive transglutaminase antibodies and no symptoms of celiac disease were divided, receiving gluten-free vs. gluten-containing diets. The former group, but not the second one, experienced a reduction in antibody titers and an increase in VitD levels [116]. However, the possibility of VitD deficiency being exclusively a consequence of AID seems unlikely, given that this relationship has been found in several studies, independently of factors such as age, body mass index, thyroid function tests (i.e., presence of hyper-, hypo-, or euthyroidism) and the presence or absence of other AIDs. Furthermore, in a study that evaluated patients with GD and 25(OH)D insufficiency, no statistically significant difference was found in the values of $25(\mathrm{OH}) \mathrm{D}$ at baseline and 1 to 2 years after hyperthyroidism therapy (with achievement of euthyroidism) [117]. Therefore, contrary to what would be expected if low levels of VitD were a consequence of the autoimmune disease, treating the autoimmune disease does not improve VitD status.

Another possibility is that the lower levels of 25(OH)D in AID are the result of a pathophysiological mechanism involved in the development of the disease; that is, VDR dysfunction caused by chronic infection by intra-phagocytic microorganisms [111]. This dysfunction could lead to lower production of the antimicrobial peptides that would usually result from activation of VDR. VDR dysfunction 
could also lead to lesser expression of 24-hydroxylase, with a consequent increase in $1,25(\mathrm{OH})_{2} \mathrm{D}$ levels. Excess $1,25(\mathrm{OH})_{2} \mathrm{D}$ has the ability to displace ligands of nuclear receptors such as $\alpha$-thyroid, glucocorticoids, and androgens, which can lead to glandular dysfunction [118]. Elevated levels of $1,25(\mathrm{OH})_{2} \mathrm{D}$ further bind to the pregnane $X$ receptor and inhibit the synthesis of $25(\mathrm{OH}) \mathrm{D}$ in the liver. In this context, the various data pointing towards a relationship between AID and VitD deficiency may be explained by the fact that the metabolite usually measured is $25(\mathrm{OH}) \mathrm{D}$ [119]. This is a counterintuitive hypothesis, with some theoretical background but with little data to support or contradict it directly, as $1,25(\mathrm{OH})_{2} \mathrm{D}$ is rarely quantified. However, some of the above-mentioned studies on VitD supplementation reported elevated PTH and normal/slightly low calcium values, associated with a deficiency of $25(\mathrm{OH}) \mathrm{D}$ at baseline with a tendency towards normalization after VitD supplementation [41,91,95]. This does not support the possibility that there is an increase in $1,25(\mathrm{OH})_{2} \mathrm{D}$ in AITD concealed by the quantification of $25(\mathrm{OH}) \mathrm{D}$. Although it may be argued that PTH level elevation and lowering of calcium levels may be explained by VDR dysfunction, it is unlikely that such alterations were susceptible to correction by VitD supplementation, as it would not correct the primary mechanism. The fact that VitD supplementation has shown some beneficial effects on autoimmunity parameters is also against this hypothesis.

Analyzing the current evidence, we conclude that, although a direct and marked contribution of VitD levels alone in the pathogenesis of AITD is unlikely, given the marked inconsistency of the data, a minor contribution is probable, as the existence of an association has been supported by the majority of the studies cited above (refer to Section 5.2. Data on vitamin D levels and autoimmune thyroid disease). Therefore, it is plausible that the levels of VitD, the polymorphisms of its receptor [85-88], and the enzymes that govern its metabolism [89] influence its regulatory capacity and, thus, it likely plays a small, yet significant, role in the development and course of AITD. It is likely that this contribution depends upon a multiplicity of other factors, such as age and gender, sex hormones [49,99], and micronutrients [100]. Genetic, epigenetic, and other endogenous and environmental factors which contribute to the predisposition to AITD may also influence this correlation, explaining some of the inconsistency in the results obtained in different populations. The above-mentioned consequences of AITD (e.g., incapacitation, lower sunlight exposure, obesity in hypothyroidism, and increased bone turnover in hyperthyroidism) and, in some cases, the coexistence of other AID may generate a vicious cycle and contribute to the observed relationship.

\section{Discussion and Conclusions}

Several questions can be raised regarding the relationship between VitD and AITD, the first one being whether such a relationship actually exists. With respect to this matter, although there is some inconsistency in the results of the studies carried out to date, most of the data point toward an association between lower VitD levels and increased risk of developing the disease and/or higher antibody titers and/or more difficulty in its treatment, especially for vitamin D deficiency. Polymorphisms in genes associated with VitD function/metabolism also appear to have some influence on the risk of AITD.

The second question concerns the exact nature of this relationship. We propose that VitD plays a small, yet significant, role in the pathogenesis of AITD, which may only be apparent when other factors that contribute to its expression are gathered. After the onset of AITD, its consequences may generate a vicious cycle, contributing to aggravation of the deficiency.

The third question, with more immediate implications on clinical practice, is the role of VitD supplementation on the prevention and/or treatment of AITD, as well as whether a supraphysiological level would be desirable. At present, there is a paucity of data establishing the exemption from harm and the presence of benefit of obtaining supraphysiological levels of $25(\mathrm{OH}) \mathrm{D}$. There are even data suggesting possible associations with increased fracture and mortality risks. Therefore, a sensitive approach is to aim for a $25(\mathrm{OH}) \mathrm{D}$ level within the reference ranges suggested in international guidelines. 
In the future, more data from investigations with a larger number of individuals, a more global scope, and involving year-round evaluations of VitD levels are necessary, in order to provide more uniform and consistent answers to these questions.

Author Contributions: Conceptualization and methodology, I.H.V., D.R. and I.P.; writing-original draft preparation, I.H.V.; review and editing, I.H.V., D.R. and I.P.; supervision, D.R. and I.P. All authors have read and agreed to the published version of the manuscript.

Funding: This research received no external funding.

Acknowledgments: The authors which to thank Elisabete Santos for her initial language corrections.

Conflicts of Interest: The authors declare no conflict of interest.

\section{References}

1. Kmiec, P.; Sworczak, K. Vitamin D in thyroid disorders. Exp. Clin. Endocrinol. Diabetes 2015, 123, 386-393.

2. Muscogiuri, G.; Mitri, J.; Mathieu, C.; Badenhoop, K.; Tamer, G.; Orio, F.; Mezza, T.; Vieth, R.; Colao, A.; Pittas, A. Mechanisms in Endocrinology: Vitamin D as a potential contributor in endocrine health and disease. Eur. J. Endocrinol. 2014, 171, R101-R110. [CrossRef] [PubMed]

3. Kim, D. The Role of Vitamin D in Thyroid Diseases. Int. J. Mol. Sci. 2017, 18, 1949. [CrossRef] [PubMed]

4. Altieri, B.; Muscogiuri, G.; Barrea, L.; Mathieu, C.; Vallone, C.V.; Mascitelli, L.; Bizzaro, G.; Altieri, V.M.; Tirabassi, G.; Balercia, G.; et al. Does vitamin D play a role in autoimmune endocrine disorders? A proof of concept. Rev. Endocr. Metab. Disord. 2017, 18, 335-346. [CrossRef]

5. Bikle, D.D. Vitamin D metabolism, mechanism of action, and clinical applications. Chem. Biol. 2014, 21, 319-329. [CrossRef] [PubMed]

6. Nettore, I.C.; Albano, L.; Ungaro, P.; Colao, A.; Macchia, P.E. Sunshine vitamin and thyroid. Rev. Endocr. Metab. Disord. 2017, 18, 347-354. [CrossRef]

7. Vondra, K.; Stárka, L.; Hampl, R. Vitamin D and Thyroid Diseases. Physiol. Res. 2015, S95-S100. [CrossRef]

8. Martins, J.S.; Palhares, M.D.O.; Teixeira, O.C.M.; Ramos, M.G. Vitamin D Status and Its Association with Parathyroid Hormone Concentration in Brazilians. J. Nutr. Metab. 2017, 2017, 1-5. [CrossRef]

9. Aranow, C. Vitamin D and the immune system. J. Investig. Med. 2011, 59, 881-886. [CrossRef]

10. Wierzbicka, J.; Piotrowska, A.; Żmijewski, M.A. The renaissance of vitamin D. Acta Biochim. Pol. 2014, 61, 679-686. [CrossRef]

11. Hossein-Nezhad, A.; Spira, A.; Holick, M.F. Influence of Vitamin D Status and Vitamin D3 Supplementation on Genome Wide Expression of White Blood Cells: A Randomized Double-Blind Clinical Trial. PLoS ONE 2013, 8, e58725. [CrossRef] [PubMed]

12. Płudowski, P.; Holick, M.F.; Pilz, S.; Wagner, C.L.; Hollis, B.W.; Grant, W.B.; Shoenfeld, Y.; Lerchbaum, E.; Llewellyn, D.J.; Kienreich, K.; et al. Vitamin D effects on musculoskeletal health, immunity, autoimmunity, cardiovascular disease, cancer, fertility, pregnancy, dementia and mortality-A review of recent evidence. Autoimmun. Rev. 2013, 12, 976-989. [CrossRef] [PubMed]

13. Theodoratou, E.; Tzoulaki, I.; Zgaga, L.; Ioannidis, A.J.P. Vitamin D and multiple health outcomes: Umbrella review of systematic reviews and meta-analyses of observational studies and randomised trials. BMJ 2014, 348, g2035. [CrossRef] [PubMed]

14. Rosen, Y.; Daich, J.; Soliman, I.; Brathwaite, E.; Shoenfeld, Y. Vitamin D and autoimmunity. Scand. J. Rheumatol. 2016, 45, 439-447. [CrossRef]

15. Skaaby, T.; Husemoen, L.L.N.; Thuesen, B.; Linneberg, A. Prospective population-based study of the association between vitamin D status and incidence of autoimmune disease. Endocrine 2015, 50, 231-238. [CrossRef]

16. Hewison, M. Vitamin D and the Immune System: New Perspectives on an Old Theme. Endocrinol. Metab. Clin. N. Am. 2010, 39, 365-379. [CrossRef]

17. Kamen, D.L.; Tangpricha, V. Vitamin D and molecular actions on the immune system: Modulation of innate and autoimmunity. J. Mol. Med. 2010, 88, 441-450. [CrossRef]

18. Nikolic, T.; Roep, B.O. Regulatory Multitasking of Tolerogenic Dendritic Cells—Lessons Taken from Vitamin D3-Treated Tolerogenic Dendritic Cells. Front. Immunol. 2013, 4, 113. [CrossRef] 
19. Ferreira, G.B.; Gysemans, C.A.; Demengeot, J.; Da Cunha, J.P.M.C.M.; Vanherwegen, A.-S.; Overbergh, L.; Van Belle, T.L.; Pauwels, F.; Verstuyf, A.; Korf, H.; et al. 1,25-Dihydroxyvitamin D3 Promotes Tolerogenic Dendritic Cells with Functional Migratory Properties in NOD Mice. J. Immunol. 2014, 192, 4210-4220. [CrossRef]

20. Şıklar, Z.; Karataş, D.; Doğu, F.; Hacıhamdioğlu, B.; Ikincioğulları, A.; Berberoğlu, M. Regulatory T Cells and Vitamin D Status in Children with Chronic Autoimmune Thyroiditis. J. Clin. Res. Pediatr. Endocrinol. 2016, 8, 276-281. [CrossRef]

21. Orgiazzi, J. Thyroid autoimmunity. Presse Medicale 2012, 41, e611-e625. [CrossRef] [PubMed]

22. Antonelli, A.; Ferrari, S.M.; Corrado, A.; Di Domenicantonio, A.; Fallahi, P. Autoimmune thyroid disorders. Autoimmun. Rev. 2015, 14, 174-180. [CrossRef] [PubMed]

23. Merrill, S.J.; Minucci, S.B. Thyroid Autoimmunity: An Interplay of Factors. In Vitamins and Hormones; Academic Press: Cambridge, MA, USA, 2018; Volume 106, pp. 129-145. [CrossRef]

24. Wiersinga, W.M. Thyroid Autoimmunity. In Paediatric Thyroidology; Karger Publishers: Basel, Switzerland, 2014; pp. 139-157. [CrossRef]

25. Wiersinga, W.M. Clinical Relevance of Environmental Factors in the Pathogenesis of Autoimmune Thyroid Disease. Endocrinol. Metab. 2016, 31, 213-222. [CrossRef] [PubMed]

26. Köhling, H.L.; Plummer, S.F.; Marchesi, J.R.; Davidge, K.S.; Ludgate, M. The microbiota and autoimmunity: Their role in thyroid autoimmune diseases. Clin. Immunol. 2017, 183, 63-74. [CrossRef]

27. Virili, C.; Fallahi, P.; Antonelli, A.; Benvenga, S.; Centanni, M. Gut microbiota and Hashimoto's thyroiditis. Rev. Endocr. Metab. Disord. 2018, 19, 293-300. [CrossRef]

28. Zhao, F.; Feng, J.; Li, J.; Zhao, L.; Liu, Y.; Chen, H.; Jin, Y.; Zhu, B.; Wei, Y. Alterations of the Gut Microbiota in Hashimoto's Thyroiditis Patients. Thyroid 2018, 28, 175-186. [CrossRef]

29. Chiara, M.; Caputo, M.; Bisceglia, A.; Samà, M.T.; Zavattaro, M.; Gianluca, A.; Pagano, L.; Prodam, F.; Paolo, M. Immunomodulatory Effects of Vitamin D in Thyroid Diseases. Nutrients 2020, 12, 1444. [CrossRef]

30. Kucukler, F.K.; Şimşek, Y.; Gorkem, U.; Dogan, B.A.; Guler, S. Relationship between gestational transient thyrotoxicosis and vitamin D. Turk. J. Med. Sci. 2016, 46, 1374-1378. [CrossRef]

31. Barchetta, I.; Baroni, M.; Leonetti, F.; De Bernardinis, M.; Bertoccini, L.; Fontana, M.; Mazzei, E.; Fraioli, A.; Cavallo, M.G. TSH levels are associated with vitamin D status and seasonality in an adult population of euthyroid adults. Clin. Exp. Med. 2015, 15, 389-396. [CrossRef]

32. Muscogiuri, G.; Tirabassi, G.; Bizzaro, G.; Orio, F.; Paschou, S.A.; Vryonidou, A.; Balercia, G.; Shoenfeld, Y.; Colao, A. Vitamin D and thyroid disease: To D or not to D? Eur. J. Clin. Nutr. 2015, 69, 291-296. [CrossRef]

33. Hamilton, A.; Newby, P.R.; Carr-Smith, J.D.; Disanto, G.; Allahabadia, A.; Armitage, M.; Brix, T.H.; Chatterjee, K.; Connell, J.M.; Hegedüs, L.; et al. Impact of Month of Birth on the Development of Autoimmune Thyroid Disease in the United Kingdom and Europe. J. Clin. Endocrinol. Metab. 2014, 99, E1459-E1465. [CrossRef] [PubMed]

34. Thvilum, M.; Brandt, F.; Brix, T.H.; Hegedüs, L. Month of birth is associated with the subsequent diagnosis of autoimmune hypothyroidism. A nationwide Danish register-based study. Clin. Endocrinol. 2017, 87, 832-837. [CrossRef] [PubMed]

35. Sivalingam, S.; Thvilum, M.; Brix, T.H.; Hegedüs, L.; Brandt, F. No link between season of birth and subsequent development of Graves' disease or toxic nodular goiter: A nationwide Danish register-based study. Endocr. Connect. 2018, 7, 1090-1095. [CrossRef] [PubMed]

36. Kyrgios, I.; Giza, S.; Tsinopoulou, V.R.; Maggana, I.; Haidich, A.-B.; Galli-Tsinopoulou, A. Seasonality of month of birth in children and adolescents with autoimmune thyroiditis: A continuing conundrum. J. Pediatr. Endocrinol. Metab. 2018, 31, 1123-1131. [CrossRef] [PubMed]

37. Mackawy, A.M.H.; Al-Ayed, B.M.; Al-Rashidi, B.M. Vitamin D Deficiency and Its Association with Thyroid Disease. Int. J. Health Sci. 2013, 7, 267-275. [CrossRef]

38. Chailurkit, L.-O.; Aekplakorn, W.; Ongphiphadhanakul, B. High Vitamin D Status in Younger Individuals Is Associated with Low Circulating Thyrotropin. Thyroid 2013, 23, 25-30. [CrossRef]

39. Zhang, Q.; Wang, Z.; Sun, M.; Cao, M.; Zhu, Z.; Fu, Q.; Gao, Y.; Mao, J.; Li, Y.; Shi, Y.; et al. Association of High Vitamin D Status with Low Circulating Thyroid-Stimulating Hormone Independent of Thyroid Hormone Levels in Middle-Aged and Elderly Males. Int. J. Endocrinol. 2014, 2014, 1-6. [CrossRef] 
40. Kim, M.; Song, E.; Oh, H.-S.; Park, S.; Kwon, H.; Jeon, M.J.; Shong, Y.K.; Kim, T.-Y.; Kim, W.G.; Kim, W.B. Vitamin D deficiency affects thyroid autoimmunity and dysfunction in iodine-replete area: Korea national health and nutrition examination survey. Endocrine 2017, 58, 332-339. [CrossRef]

41. Vondra, K.; Bílek, R.; Matucha, P.; Salátová, M.; Vosátková, M.; Stárka, L.; Hampl, R. Vitamin D Supplementation Changed Relationships, Not Levels of Metabolic-Hormonal Parameters in Autoimmune Thyroiditis. Physiol. Res. 2017, 26, S409-S417. [CrossRef]

42. Kivity, S.; Agmon-Levin, N.; Zisappl, M.; Shapira, Y.; Nagy, E.V.; Dankó, K.; Szekanecz, Z.; Langevitz, P.; Shoenfeld, Y. Vitamin D and autoimmune thyroid diseases. Cell. Mol. Immunol. 2011, 8, 243-247. [CrossRef]

43. Unal, A.D.; Tarcin, O.; Parildar, H.; Cigerli, O.; Eroglu, H.; Demirag, N.G. Vitamin D deficiency is related to thyroid antibodies in autoimmune thyroiditis. Cent. Eur. J. Immunol. 2014, 39, 493-497. [CrossRef] [PubMed]

44. Ma, J.; Wu, D.; Li, C.; Fan, C.; Chao, N.; Liu, J.; Li, Y.; Wang, R.; Miao, W.; Guan, H.; et al. Lower Serum 25-Hydroxyvitamin D Level is Associated With 3 Types of Autoimmune Thyroid Diseases. Medicine 2015, 94, e1639. [CrossRef] [PubMed]

45. Wang, J.; Lv, S.; Chen, G.; Gao, C.; He, J.; Zhong, H.; Xu, Y. Meta-Analysis of the Association between Vitamin D and Autoimmune Thyroid Disease. Nutrients 2015, 7, 2485-2498. [CrossRef] [PubMed]

46. Muscogiuri, G.; Palomba, S.; Caggiano, M.; Tafuri, D.; Colao, A.; Orio, F. Low 25 (OH) vitamin D levels are associated with autoimmune thyroid disease in polycystic ovary syndrome. Endocrine 2016, 53, 538-542. [CrossRef] [PubMed]

47. D'Aurizio, F.; Villalta, D.; Metus, P.; Doretto, P.; Tozzoli, R. Is vitamin D a player or not in the pathophysiology of autoimmune thyroid diseases? Autoimmun. Rev. 2015, 14, 363-369. [CrossRef]

48. Effraimidis, G.; Badenhoop, K.; Tijssen, J.G.P.; Wiersinga, W.M. Vitamin D deficiency is not associated with early stages of thyroid autoimmunity. Eur. J. Endocrinol. 2012, 167, 43-48. [CrossRef]

49. Choi, Y.M.; Kim, W.G.; Kim, T.-Y.; Bae, S.J.; Kim, H.-K.; Jang, E.K.; Jeon, M.J.; Han, J.M.; Lee, S.H.; Baek, J.H.; et al. Low Levels of Serum Vitamin D3 Are Associated with Autoimmune Thyroid Disease in Pre-Menopausal Women. Thyroid 2014, 24, 655-661. [CrossRef]

50. Kim, C.-Y.; Lee, Y.J.; Choi, J.H.; Lee, S.Y.; Lee, H.Y.; Jeong, D.H.; Choi, Y.J. The Association between Low Vitamin D Status and Autoimmune Thyroid Disease in Korean Premenopausal Women: The 6th Korea National Health and Nutrition Examination Survey, 2013-2014. Korean J. Fam. Med. 2019, 40, 323-328. [CrossRef]

51. Tamer, G.; Arik, S.; Tamer, I.; Coksert, D. Relative Vitamin D Insufficiency in Hashimoto's Thyroiditis. Thyroid 2011, 21, 891-896. [CrossRef]

52. Bozkurt, N.; Karbek, B.; Uçan, B.; Sahin, M.; Cakal, E.; Özbek, M.; Delibasi, T. The Association between Severity of Vitamin D Deficiency and Hashimoto's Thyroiditis. Endocr. Prat. 2013, 19, 479-484. [CrossRef]

53. Mansournia, N.; Mansournia, M.A.; Saeedi, S.; Dehghan, J. The association between serum 25OHD levels and hypothyroid Hashimoto's thyroiditis. J. Endocrinol. Investig. 2014, 37, 473-476. [CrossRef] [PubMed]

54. Maciejewski, A.; Wójcicka, M.; Roszak, M.; Losy, J.; Lacka, K. Assessment of Vitamin D Level in Autoimmune Thyroiditis Patients and a Control Group in the Polish Population. Adv. Clin. Exp. Med. 2015, 24, 801-806. [CrossRef] [PubMed]

55. Kim, H. Low vitamin D status is associated with hypothyroid Hashimoto's thyroiditis. Hormones 2016. [CrossRef] [PubMed]

56. Giovinazzo, S.; Vicchio, T.M.; Certo, R.; Alibrandi, A.; Palmieri, O.; Campennì, A.; Cannavò, S.; Trimarchi, F.; Ruggeri, R.M. Vitamin D receptor gene polymorphisms/haplotypes and serum 25(OH)D3 levels in Hashimoto's thyroiditis. Endocrine 2017, 55, 599-606. [CrossRef] [PubMed]

57. Ke, W.; Sun, T.; Zhang, Y.; He, L.; Wu, Q.; Liu, J.; Zha, B. 25-Hydroxyvitamin D serum level in Hashimoto's thyroiditis, but not Graves' disease is relatively deficient. Endocr. J. 2017, 64, 581-587. [CrossRef] [PubMed]

58. De Pergola, G.; Triggiani, V.; Bartolomeo, N.; Giagulli, V.A.; Anelli, M.; Masiello, M.; Candita, V.; De Bellis, D.; Silvestris, F. Low 25 Hydroxyvitamin D Levels are Independently Associated with Autoimmune Thyroiditis in a Cohort of Apparently Healthy Overweight and Obese Subjects. Endocr. Metab. Immune Disord. Drug Targets 2018, 18, 646-652. [CrossRef]

59. Muscogiuri, G.; Mari, D.; Prolo, S.; Fatti, L.M.; Cantone, M.C.; Garagnani, P.; Arosio, B.; Di Somma, C.; Vitale, G. 25 Hydroxyvitamin D Deficiency and Its Relationship to Autoimmune Thyroid Disease in the Elderly. Int. J. Environ. Res. Public Health 2016, 13, 850. [CrossRef] 
60. Sönmezgöz, E.; Ozer, S.; Yılmaz, R.; Bilge, S.; Önder, Y.; Bütün, I. Hypovitaminosis D in Children with Hashimotos Thyroiditis. Rev. Méd. Chile 2016, 144, 611-616. [CrossRef]

61. Evliyaoğlu, O.; Acar, M.; Özcabı, B.; Erginoz, E.; Bucak, F.; Ercan, O.; Kucur, M. Vitamin D Deficiency and Hashimoto's Thyroiditis in Children and Adolescents: A Critical Vitamin D Level for This Association? J. Clin. Res. Pediatr. Endocrinol. 2015, 7, 128-133. [CrossRef]

62. Metwalley, K.A.; Farghaly, H.S.; Sherief, T.; Elderwy, A. Vitamin D status in children and adolescents with autoimmune thyroiditis. J. Endocrinol. Investig. 2016, 39, 793-797. [CrossRef]

63. Çamurdan, O.M.; Döğer, E.; Bideci, A.; Celik, N.; Cinaz, P. Vitamin D status in children with Hashimoto thyroiditis. J. Pediatr. Endocrinol. Metab. 2012, 25, 467-470. [CrossRef] [PubMed]

64. Demir, K.; Keskin, M.; Kör, Y.; Karaoglan, M.; Bülbül, Ö.G. Autoimmune thyroiditis in children and adolescents with type 1 diabetes mellitus is associated with elevated IgG4 but not with low vitamin D. Hormones 2014, 13, 361-368. [CrossRef] [PubMed]

65. Arslan, M.S.; Topaloglu, O.; Uçan, B.; Karakose, M.; Karbek, B.; Tutal, E.; Çaliskan, M.; Ginis, Z.; Cakal, E.; Sahin, M.; et al. Isolated Vitamin D Deficiency Is Not Associated with Nonthyroidal Illness Syndrome, but with Thyroid Autoimmunity. Sci. World J. 2015, 2015, 1-5. [CrossRef] [PubMed]

66. Shin, D.Y.; Kim, K.J.; Kim, D.; Hwang, S.; Lee, E.J. Low Serum Vitamin D Is Associated with Anti-Thyroid Peroxidase Antibody in Autoimmune Thyroiditis. Yonsei Med. J. 2014, 55, 476-481. [CrossRef]

67. Goswami, R.; Marwaha, R.K.; Gupta, N.; Tandon, N.; Sreenivas, V.; Tomar, N.; Ray, D.; Kanwar, R.; Agarwal, R. Prevalence of vitamin D deficiency and its relationship with thyroid autoimmunity in Asian Indians: A community-based survey. Br. J. Nutr. 2009, 102, 382-386. [CrossRef]

68. Wang, X.; Zynat, J.; Guo, Y.; Osiman, R.; Tuhuti, A.; Zhao, H.; Abdunaimu, M.; Wang, H.; Jin, X.; Xing, S. Low Serum Vitamin D Is Associated with Anti-Thyroid-Globulin Antibody in Female Individuals. Int. J. Endocrinol. 2015, 2015, 1-6. [CrossRef]

69. Yasmeh, J.; Farpour, F.; Rizzo, V.; Kheradnam, S.; Sachmechi, I. Hashimoto thyroiditis not associated with vitamin D deficiency. Endocr. Pract. 2016, 22, 809-813. [CrossRef]

70. Xu, J.; Zhu, X.-Y.; Sun, H.; Xu, X.-Q.; Xu, S.-A.; Suo, Y.; Cao, L.-J.; Zhou, Q.; Yu, H.-J.; Cao, W.-Z. Low vitamin D levels are associated with cognitive impairment in patients with Hashimoto thyroiditis. BMC Endocr. Disord. 2018, 18, 87. [CrossRef]

71. Krysiak, R.; Szkróbka, W.; Okopień, B. Moderate-dose simvastatin therapy potentiates the effect of vitamin D on thyroid autoimmunity in levothyroxine-treated women with Hashimoto's thyroiditis and vitamin D insufficiency. Pharmacol. Rep. 2018, 70, 93-97. [CrossRef]

72. Krysiak, R.; Szkróbka, W.; Okopień, B. The Relationship between Statin Action on Thyroid Autoimmunity and Vitamin D Status: A Pilot Study. Exp. Clin. Endocrinol. Diabetes 2019, 6, 23-28. [CrossRef]

73. Misharin, A.V.; Hewison, M.; Chen, C.-R.; Lagishetty, V.; Aliesky, H.A.; Mizutori, Y.; Rapoport, B.; McLachlan, S.M. Vitamin D Deficiency Modulates Graves' Hyperthyroidism Induced in BALB/c Mice by Thyrotropin Receptor Immunization. Endocrinology 2009, 150, 1051-1060. [CrossRef] [PubMed]

74. Yasuda, T.; Okamoto, Y.; Hamada, N.; Miyashita, K.; Takahara, M.; Sakamoto, F.; Miyatsuka, T.; Kitamura, T.; Katakami, N.; Kawamori, D.; et al. Serum vitamin D levels are decreased and associated with thyroid volume in female patients with newly onset Graves' disease. Endocrine 2012, 42, 739-741. [CrossRef] [PubMed]

75. Zhang, H.; Liang, L.; Xie, Z. Low Vitamin D Status is Associated with Increased Thyrotropin-Receptor Antibody Titer in Graves Disease. Endocr. Pract. 2015, 21, 258-263. [CrossRef] [PubMed]

76. Planck, T.; Shahida, B.; Malm, J.; Manjer, J. Vitamin D in Graves Disease: Levels, Correlation with Laboratory and Clinical Parameters, and Genetics. Eur. Thyroid. J. 2018, 7, 27-33. [CrossRef]

77. Choudhury, A.K.; Mangaraj, S.; Swain, B.M.; Sarangi, P.K.; Mohanty, B.K.; Baliarsinha, A.K. Evaluation of vitamin D status and its impact on thyroid related parameters in new onset Graves' disease-A cross-sectional observational study. Indian J. Endocrinol. Metab. 2019, 23, 35-39. [CrossRef]

78. Xu, M.-Y.; Cao, B.; Yin, J.; Wang, D.-F.; Chen, K.-L.; Lu, Q.-B. Vitamin D and Graves' Disease: A Meta-Analysis Update. Nutrients 2015, 7, 3813-3827. [CrossRef]

79. Yasuda, T.; Okamoto, Y.; Hamada, N.; Miyashita, K.; Takahara, M.; Sakamoto, F.; Miyatsuka, T.; Kitamura, T.; Katakami, N.; Kawamori, D.; et al. Serum vitamin D levels are decreased in patients without remission of Graves' disease. Endocrine 2013, 43, 230-232. [CrossRef]

80. Ahn, H.Y.; Chung, Y.J.; Cho, B.Y. Serum 25-hydroxyvitamin D might be an independent prognostic factor for Graves disease recurrence. Medicine 2017, 96, e7700. [CrossRef] 
81. Li, X.; Wang, G.; Lu, Z.; Chen, M.; Tan, J.; Fang, X. Serum 25-hydroxyvitamin D predict prognosis in radioiodine therapy of Graves' disease. J. Endocrinol. Investig. 2015, 38, 753-759. [CrossRef]

82. Komarovskiy, K.; Raghavan, S. Hypocalcemia Following Treatment with Radioiodine in a Child with Graves' Disease. Thyroid 2012, 22, 218-222. [CrossRef]

83. Miyashita, K.; Yasuda, T.; Kaneto, H.; Kuroda, A.; Kitamura, T.; Otsuki, M.; Okamoto, Y.; Hamada, N.; Matsuhisa, M.; Shimomura, I. A Case of Hypocalcemia with Severe Vitamin D Deficiency following Treatment for Graves' Disease with Methimazole. Case Rep. Endocrinol. 2013, 2013, 1-4. [CrossRef] [PubMed]

84. Krysiak, R.; Kowalska, B.; Okopień, B. Serum 25-Hydroxyvitamin D and Parathyroid Hormone Levels in Non-Lactating Women with Post-Partum Thyroiditis: The Effect ofl-Thyroxine Treatment. Basic Clin. Pharmacol. Toxicol. 2015, 116, 503-507. [CrossRef] [PubMed]

85. Gao, X.-R.; Yu, Y. Meta-Analysis of the Association between Vitamin D Receptor Polymorphisms and the Risk of Autoimmune Thyroid Disease. Int. J. Endocrinol. 2018, 2018, 1-15. [CrossRef] [PubMed]

86. Zhou, H.; Xu, C.; Gu, M. Vitamin D receptor (VDR) gene polymorphisms and Graves' disease: A meta-analysis. Clin. Endocrinol. 2009, 70, 938-945. [CrossRef]

87. Feng, M.; Li, H.; Chen, S.-F.; Li, W.-F.; Zhang, F.-B. Polymorphisms in the vitamin D receptor gene and risk of autoimmune thyroid diseases: A meta-analysis. Endocrine 2013, 43, 318-326. [CrossRef]

88. Veneti, S.; Anagnostis, P.; Adamidou, F.; Artzouchaltzi, A.-M.; Boboridis, K.; Kita, M. Association between vitamin D receptor gene polymorphisms and Graves' disease: A systematic review and meta-analysis. Endocrine 2019, 65, 244-251. [CrossRef]

89. Inoue, N.; Watanabè, M.; Ishido, N.; Katsumata, Y.; Kagawa, T.; Hidaka, Y.; Iwatani, Y. The functional polymorphisms of VDR, GC and CYP2R1 are involved in the pathogenesis of autoimmune thyroid diseases. Clin. Exp. Immunol. 2014, 178, 262-269. [CrossRef]

90. Mazokopakis, E.E.; Papadomanolaki, M.G.; Tsekouras, K.C.; Evangelopoulos, A.D.; Kotsiris, D.A.; Tzortzinis, A.A. Is vitamin D related to pathogenesis and treatment of Hashimoto's thyroiditis? Hell. J. Nucl. Med. 2015, 18, 222-227.

91. Mukhopadhyay, S.; Chaudhary, S.; Dutta, D.; Kumar, M.; Saha, S.; Mondal, S.A.; Kumar, A. Vitamin D supplementation reduces thyroid peroxidase antibody levels in patients with autoimmune thyroid disease: An open-labeled randomized controlled trial. Indian J. Endocrinol. Metab. 2016, 20, 391-398. [CrossRef]

92. Krysiak, R.; Szkróbka, W.; Okopień, B. The Effect of Vitamin D on Thyroid Autoimmunity in Levothyroxine-Treated Women with Hashimoto's Thyroiditis and Normal Vitamin D Status. Exp. Clin. Endocrinol. Diabetes 2017, 125, 229-233. [CrossRef]

93. Krysiak, R.; Szkróbka, W.; Okopień, B. The effect of vitamin D and selenomethionine on thyroid antibody titers, hypothalamic-pituitary-thyroid axis activity and thyroid function tests in men with Hashimoto's thyroiditis: A pilot study. Pharmacol. Rep. 2019, 71, 243-247. [CrossRef]

94. Chahardoli, R.; Saboor-Yaraghi, A.-A.; Amouzegar, A.; Khalili, D.; Vakili, A.Z.; Azizi, F. Can Supplementation with Vitamin D Modify Thyroid Autoantibodies (Anti-TPO Ab, Anti-Tg Ab) and Thyroid Profile (T3, T4, TSH) in Hashimoto's Thyroiditis? A Double Blind, Randomized Clinical Trial. Horm. Metab. Res. 2019, 51, 296-301. [CrossRef] [PubMed]

95. Krysiak, R.; Kowalcze, K.; Okopień, B. The effect of vitamin D on thyroid autoimmunity in non-lactating women with postpartum thyroiditis. Eur. J. Clin. Nutr. 2016, 70, 637-639. [CrossRef] [PubMed]

96. Dizdar, O.S.; Şimşek, Y.; Çakır, I.; Yetmis, M.; Başpinar, O.; Gokay, F. Effects of Vitamin D treatment on thyroid autoimmunity. J. Res. Med. Sci. 2016, 21, 85. [CrossRef] [PubMed]

97. Wang, S.; Wu, Y.; Zuo, Z.; Zhao, Y.; Wang, K. The effect of vitamin D supplementation on thyroid autoantibody levels in the treatment of autoimmune thyroiditis: A systematic review and a meta-analysis. Endocrine 2018, 59, 499-505. [CrossRef] [PubMed]

98. Koehler, V.F.; Filmann, N.; Mann, W.A. Vitamin D Status and Thyroid Autoantibodies in Autoimmune Thyroiditis. Horm. Metab. Res. 2019, 51, 792-797. [CrossRef]

99. Krysiak, R.; Kowalcze, K.; Okopień, B. The effect of vitamin D on thyroid autoimmunity in euthyroid men with autoimmune thyroiditis and testosterone deficiency. Pharmacol. Rep. 2019, 71, 798-803. [CrossRef]

100. Krysiak, R.; Kowalcze, K.; Okopień, B. Selenomethionine potentiates the impact of vitamin D on thyroid autoimmunity in euthyroid women with Hashimoto's thyroiditis and low vitamin D status. Pharmacol. Rep. 2019, 71, 367-373. [CrossRef] 
101. Mirhosseini, N.; Brunel, L.; Muscogiuri, G.; Kimball, S. Physiological serum 25-hydroxyvitamin D concentrations are associated with improved thyroid function-observations from a community-based program. Endocrine 2017, 58, 563-573. [CrossRef]

102. Cho, Y.Y.; Chung, Y.J. Vitamin D supplementation does not prevent the recurrence of Graves' disease. Sci. Rep. 2020, 10, 16-17. [CrossRef]

103. Grove-Laugesen, D.; Malmstroem, S.; Ebbehoj, E.; Riis, A.L.; Watt, T.; Hansen, K.W.; Rejnmark, L. Effect of 9 months of vitamin D supplementation on arterial stiffness and blood pressure in Graves' disease: A randomized clinical trial. Endocrine 2019, 66, 386-397. [CrossRef] [PubMed]

104. Grove-Laugesen, D.; Cramon, P.K.; Malmstroem, S.; Ebbehoj, E.; Watt, T.; Hansen, K.W.; Rejnmark, L. Effects of Supplemental Vitamin D on Muscle Performance and Quality of Life in Graves' Disease: A Randomized Clinical Trial. Thyroid 2020, 30, 661-671. [CrossRef] [PubMed]

105. Sanders, K.M.; Nicholson, G.C.; Ebeling, P.R. Is High Dose Vitamin D Harmful? Calcif. Tissue Int. 2013, 92, 191-206. [CrossRef] [PubMed]

106. Durup, D.; Jørgensen, H.L.; Christensen, J.; Schwarz, P.; Heegaard, A.-M.; Lind, B. A Reverse J-Shaped Association of All-Cause Mortality with Serum 25-Hydroxyvitamin D in General Practice: The CopD Study. J. Clin. Endocrinol. Metab. 2012, 97, 2644-2652. [CrossRef]

107. Institute of Medicine. Dietary Reference Intakes for Calcium and Vitamin D; The National Academies Press: Cambridge, MA, USA, 2011.

108. Holick, M.F.; Binkley, N.; Bischoff-Ferrari, H.A.; Gordon, C.M.; Hanley, D.A.; Heaney, R.P.; Murad, M.; Weaver, C.M. Evaluation, Treatment, and Prevention of Vitamin D Deficiency: An Endocrine Society Clinical Practice Guideline. J. Clin. Endocrinol. Metab. 2011, 96, 1911-1930. [CrossRef]

109. Bizzaro, G.; Shoenfeld, Y. Vitamin D and thyroid autoimmune diseases: The known and the obscure. Immunol. Res. 2015, 61, 107-109. [CrossRef]

110. Kozai, M.; Yamamoto, H.; Ishiguro, M.; Harada, N.; Masuda, M.; Kagawa, T.; Takei, Y.; Otani, A.; Nakahashi, O.; Ikeda, S.; et al. Thyroid Hormones Decrease Plasma 1 $\alpha$,25-Dihydroxyvitamin D Levels Through Transcriptional Repression of the Renal 25-Hydroxyvitamin D31 $\alpha$-Hydroxylase Gene (CYP27B1). Endocrinology 2013, 154, 609-622. [CrossRef]

111. Hu, S.; Rayman, M.P. Multiple Nutritional Factors and the Risk of Hashimoto's Thyroiditis. Thyroid 2017, 27, 597-610. [CrossRef]

112. Botelho, I.M.B.; Neto, A.M.; Silva, C.A.; Tambascia, M.A.; Alegre, S.M.; Zantut-Wittmann, D.E. Vitamin D in Hashimoto's thyroiditis and its relationship with thyroid function and inflammatory status. Endocr. J. 2018, 65, 1029-1037. [CrossRef]

113. Kawicka, A.; Regulska-Ilow, B. Metabolic disorders and nutritional status in autoimmune thyroid diseases. Postępy Hig. Med. Dośw. 2015, 69, 80-90. [CrossRef]

114. Walker, M.D.; Zylberberg, H.M.; Green, P.H.R.; Katz, M.S. Endocrine complications of celiac disease: A case report and review of the literature. Endocr. Res. 2019, 44, 27-45. [CrossRef] [PubMed]

115. Roy, A.; Laszkowska, M.; Sundström, J.; Lebwohl, B.; Green, P.H.; Kämpe, O.; Ludvigsson, J.F. Prevalence of Celiac Disease in Patients with Autoimmune Thyroid Disease: A Meta-Analysis. Thyroid 2016, 26, 880-890. [CrossRef] [PubMed]

116. Krysiak, R.; Szkróbka, W.; Okopień, B. The Effect of Gluten-Free Diet on Thyroid Autoimmunity in Drug-Naïve Women with Hashimoto's Thyroiditis: A Pilot Study. Exp. Clin. Endocrinol. Diabetes 2019, 127, 417-422. [CrossRef] [PubMed]

117. Jyotsna, V.P.; Sahoo, A.; Singh, A.K.; Sreenivas, V.; Gupta, N. Bone mineral density in patients of Graves disease pre- \& post-treatment in a predominantly vitamin D deficient population. Indian J. Med. Res. 2012, 135, 36-41. [CrossRef] [PubMed]

118. Proal, A.D.; Albert, P.J.; Marshall, T.G. Dysregulation of the Vitamin D Nuclear Receptor May Contribute to the Higher Prevalence of Some Autoimmune Diseases in Women. Ann. N. Y. Acad. Sci. 2009, 1173, 252-259. [CrossRef]

119. Waterhouse, J.C.; Perez, T.H.; Albert, P.J. Reversing Bacteria-Induced Vitamin D Receptor Dysfunction Is Key to Autoimmune Disease. Ann. N. Y. Acad. Sci. 2009, 1173, 757-765. [CrossRef] 